\title{
Low density lipoprotein cholesterol and all- cause mortality rate: findings from a study on Japanese community-dwelling persons
}

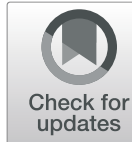

Ryuichi Kawamoto ${ }^{1,2^{*}}$ (D), Asuka Kikuchi ${ }^{1,2}$, Taichi Akase $^{2}$, Daisuke Ninomiya ${ }^{1,2}$ and Teru Kumagi ${ }^{1}$

\begin{abstract}
Background: Low-density lipoprotein cholesterol (LDL-C) independently impacts aging-related health outcomes and plays a critical role in cardiovascular diseases (CVDs). However, there are limited predictive data on all-cause mortality, especially for the Japanese community population. In this study, it was examined whether LDL-C is related to survival prognosis based on 7 or 10 years of follow-up.
\end{abstract}

Methods: Participants included 1610 men ( $63 \pm 14$ years old) and 2074 women ( $65 \pm 12$ years old) who participated in the Nomura cohort study conducted in 2002 (first cohort) and 2014 (second cohort) and who continued throughout the follow-up periods (follow-up rates: 94.8 and 98.0\%). Adjusted relative risk estimates were obtained for all-cause mortality using a basic resident register. The data were analyzed by a Cox regression with the time variable defined as the length between the age at the time of recruitment and that at the end of the study (the age of death or censoring), and risk factors including gender, age, body mass index (BMI), presence of diabetes, lipid levels, renal function, serum uric acid levels, blood pressure, and history of smoking, drinking, and CVD.

Results: Of the 3684 participants, 326 (8.8\%) were confirmed to be deceased. Of these, 180 were men (11.2\% of all men) and 146 were women (7.0\% of all women). Lower LDL-C levels, gender (male), older age, BMI under $18.5 \mathrm{~kg} /$ $\mathrm{m}^{2}$, and the presence of diabetes were significant predictors for all-cause mortality. Compared with individuals with LDL-C levels of $144 \mathrm{mg} / \mathrm{dL}$ or higher, the multivariable-adjusted Hazard ratio (and 95\% confidence interval) for allcause mortality was 2.54 (1.58-4.07) for those with LDL-C levels below $70 \mathrm{mg} / \mathrm{dL}, 1.71$ (1.15-2.54) for those with $\mathrm{LDL}-\mathrm{C}$ levels between $70 \mathrm{mg} / \mathrm{dL}$ and $92 \mathrm{mg} / \mathrm{dL}$, and 1.21 (0.87-1.68) for those with LDL-C levels between $93 \mathrm{mg} / \mathrm{dL}$ and $143 \mathrm{mg} / \mathrm{dL}$. This association was particularly significant among participants who were male $(P$ for interaction $=$ 0.039) and had CKD ( $P$ for interaction $=0.015)$.

Conclusions: There is an inverse relationship between LDL-C levels and the risk of all-cause mortality, and this association is statistically significant.

Keywords: Low-density lipoprotein cholesterol, All-cause mortality, Community-dwelling persons, Cohort study

\footnotetext{
* Correspondence: rykawamo@m.ehime-u.ac.jp

'Department of Community Medicine, Ehime University Graduate School of Medicine, Toon-city, Ehime 791-0295, Japan

${ }^{2}$ Department of Internal Medicine, Seiyo Municipal Nomura Hospital, 9-53

Nomura, Nomura-cho, Seiyo-city, Ehime 797-1212, Japan
}

(c) The Author(s). 2021 Open Access This article is licensed under a Creative Commons Attribution 4.0 International License, which permits use, sharing, adaptation, distribution and reproduction in any medium or format, as long as you give appropriate credit to the original author(s) and the source, provide a link to the Creative Commons licence, and indicate if changes were made. The images or other third party material in this article are included in the article's Creative Commons licence, unless indicated otherwise in a credit line to the material. If material is not included in the article's Creative Commons licence and your intended use is not permitted by statutory regulation or exceeds the permitted use, you will need to obtain permission directly from the copyright holder. To view a copy of this licence, visit http://creativecommons.org/licenses/by/4.0/ The Creative Commons Public Domain Dedication waiver (http://creativecommons.org/publicdomain/zero/1.0/) applies to the data made available in this article, unless otherwise stated in a credit line to the data. 


\section{Introduction}

Numerous researchers have highlighted that lowdensity lipoprotein cholesterol (LDL-C) is a key risk factor associated with cardiovascular diseases (CVDs) [1]. Randomized controlled trials on the impact of lipid-lowering therapies have elucidated that reducing LDL-C levels lowers the risk of developing atherosclerotic CVD [2-5].

Research has offered contrasting findings on the association between LDL-C levels and CVD-related mortality. While some studies have shown a positive association [6], others present U-shaped associations [7]. Similarly, findings on the association between LDL-C levels and the risk of all-cause mortality remain contradictory. Whereas some research indicates a counterintuitive reverse association (increased levels of LDL-C reduce mortality) [8-11], others conclude that LDL-C levels are irrelevant [12, 13]. The varying results can be attributed to differences in the race, age, and gender of the targeted participants.

To address these inconsistencies, this study aimed to investigate whether LDL-C is related to survival prognosis based on 7 or 10 years of follow-up among Japanese community-dwelling persons.

\section{Methods}

\section{Study design and participants}

This prospective cohort analysis is part of the Nomura studies [14] initiated in 2002 (first cohort) and 2014 (second cohort). Participants were recruited from the rural areas of Ehime Prefecture, Japan, with a focus on those who had undergone a community-based annual health check at the Nomura Health and Welfare Center. The first cohort included a total of 3164 people and the second cohort had 1832 people, all of whom were between the ages of 22 and 95 years. All procedures were carried out in accordance with relevant guidelines and regulations. A self-administered questionnaire was used to obtain data on participants' physical activity, medical history, current condition, and medication. Figure 1 shows the flowchart for the inclusion and exclusion of participants. Follow-up assessments were conducted after a 10-year interval for the first cohort and a 7-year interval for the second cohort. Participants' living status was confirmed using Japan's Basic Resident Register. The Nomura studies did not provide information on causes of death or new onset of CVD [14]. This study examined evaluation data for the first and second cohorts $(N=3684)$. The study protocol was reviewed and approved by the Ehime University Hospital Institutional Review Board (IRB) (1903018). All participants provided written informed consent.

\section{Evaluation of risk factors}

Demographic and risk factor data were obtained from clinical files. Body mass index (BMI) was estimated as weight $(\mathrm{kg})$ divided by height $\left(\mathrm{m}^{2}\right)$. Smoking status (packs-year) was calculated by multiplying the number of packs of cigarettes smoked per day by the number of years the person has smoked. Accordingly, participants were categorized as non-smokers, ex-smokers, light smokers $(<20$ packs-year), or heavy smokers $(\geq 20$ packs-year). The Japanese liquor unit $(22.9 \mathrm{~g}$ ethanol) was referenced to measure daily alcohol consumption. Participants were categorized as non-drinkers, occasional drinkers ( $<1$ unit/day), light daily drinkers (1-2 units/ day), and heavy daily drinkers (2-3 units/day). None of the participants consumed more than 3 units/day. Systolic blood pressure (SBP) and diastolic blood pressure (DBP) were estimated by an automatic sphygmomanometer. To record both types of blood pressure, participants were asked to rest for at least 5 mins., after which an appropriately sized cuff was placed on the participant's right upper arm while seated. The average of two consecutive measurements was used for the analysis. Triglyceride (TG), high-density lipoprotein cholesterol (HDLC), LDL-C, serum uric acid (SUA), and blood glucose (BG) levels were measured during overnight fasting. The glomerular filtration ratio (eGFR) was estimated by modifying the chronic kidney disease epidemiology collaboration (CKD-EPI) equation with a Japanese coefficient: Male, $\mathrm{Cr} \leq 0.9 \mathrm{mg} / \mathrm{dl}, 141 \times(\mathrm{Cr} / 0.9)^{-0.411} \times 0.993$ age $\times 0.813 ; \mathrm{Cr}>0.9 \mathrm{mg} / \mathrm{dl}, 141 \times(\mathrm{Cr} / 0.9)^{-1.209} \times 0.993$ age $\times 0.813$; Female, $\mathrm{Cr} \leq 0.7 \mathrm{mg} / \mathrm{dl}, 144 \times(\mathrm{Cr} / 0.7){ }^{-}$ $0.329 \times 0.993{ }^{\text {age }} \times 0.813 ; \mathrm{Cr}>0.7 \mathrm{mg} / \mathrm{dl}, 144 \times(\mathrm{Cr} / 0.7)^{-}$ $1.209 \times 0.993$ age $\times 0.813$ [15].

Participants were said to have hypertension if their SBP was $140 \mathrm{mmHg}$ or higher, their DBP was $90 \mathrm{mmHg}$ or higher, or they were on antihypertensive medication. Further, participants were classified as having hypertriglyceridemia if their TG levels were $150 \mathrm{mg} / \mathrm{dL}$ or higher and as having low HDL cholesterolemia if their HDL-C levels were below $40 \mathrm{mg} / \mathrm{dL}$. Those on antidiabetic medication and with BG levels of $126 \mathrm{mg} / \mathrm{dL}$ or higher were categorized as diabetic. Use of a SUA-lowering medication or SUA levels of $7.0 \mathrm{mg} / \mathrm{dL}$ or higher were indicators of hyperuricemia. Chronic kidney disease (CKD) was defined as an eGFR under $60 \mathrm{~mL} / \mathrm{min} / 1.73 \mathrm{~m}^{2}$. Ischemic heart disease, ischemic stroke, and peripheral vascular disease were classified as CVD.

\section{Statistical analysis}

All data were analyzed using IBM SPSS Statistics (version 26.0; SPSS Inc., Chicago, IL, United States). Normally distributed data are presented as the mean \pm standard deviation and non-normally distributed data are expressed as median values (interquartile range) 


\section{Nomura Cohort}

\section{Wave 1}

\begin{tabular}{l}
$\begin{array}{l}\text { Wave } 1 \text { in 2002, } N=3,164 \\
(1,355 \text { men aged } 59 \pm 15 \text { years and } 1,809 \text { women aged } 62 \pm 13 \text { years })\end{array}$ \\
$\begin{array}{l}\text { Excluded } \\
\text { Missing data, } N=389 \\
(1,200 \text { men aged } 60 \pm 15 \text { years and } 1,575 \text { women aged } 63 \pm 12 \text { years })\end{array}$ \\
\begin{tabular}{ll|} 
Included in the cohort study from 2002 to $2012, N=2,775$ \\
Moved, $N=68$ \\
$(1,122$ men aged $61 \pm 14$ years and 1,510 women aged $63 \pm 12$ years $)$
\end{tabular} \\
\hline
\end{tabular}

\section{Wave 2}

\begin{tabular}{|l|l|}
$\begin{array}{l}\text { Wave } 2 \text { in } 2014, N=1,832 \\
(818 \text { men aged } 68 \pm 12 \text { years and } 1,014 \text { women aged } 68 \pm 11 \text { years })\end{array}$ \\
$\begin{array}{l}\text { Excluded } \\
\text { Missing data, } N=42 \text {; Duplicate cases, } N=716\end{array}$ \\
\begin{tabular}{|l|} 
Included in the cohort study from 2014 to $2020, N=1,074$ \\
(806 men aged $69 \pm 11$ years and 985 women aged $69 \pm 9$ years $)$
\end{tabular} \\
$\begin{array}{l}\text { Moved, } N=22 \\
\text { (488 men aged } 67 \pm 11 \text { years and } 564 \text { women aged } 68 \pm 10 \text { years) }\end{array}$ \\
\hline
\end{tabular}

\section{Wave $1+$ Wave 2}

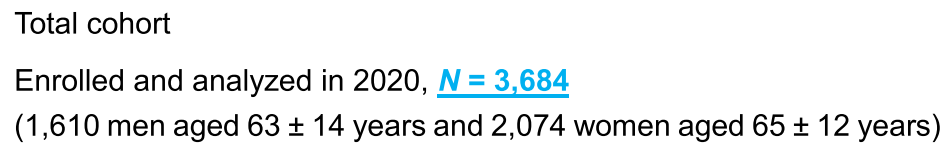

Fig. 1 Flowchart of participants

(e.g., for TG and BG levels). Parameters with nonnormal distributions were log-transformed, and the transformed values were used in all analyses. Participants were divided into four groups on the basis of LDL-C level (very low: $\leq 69$; low: 70-92; medium: 93-143; high: $\geq 144 \mathrm{mg} / \mathrm{dL}$ ). Student's $t$-test or an analysis of variance (ANOVA) was conducted on continuous data and a $x^{2}$ test was used on categorical data to analyze for differences in means and prevalence among the groups. Next, a Cox proportional hazard regression was performed to estimate hazard ratios (HRs) and 95\% confidence intervals (CIs). The time variable was defined as the length between the age at the time of recruitment and that at the end of the study (the age of death or censoring). Analyses were adjusted for gender, age, BMI, smoking and drinking habits, history of CVD, hypertension, hypertriglyceridemia, low HDL-cholesterolemia, diabetes, CKD, use of lipid-lowering medication, and LDL$\mathrm{C}$ group. Subgroup analyses were performed to determine if the observed association between LDL-C levels and all-cause mortality was consistent. Next, a likelihood ratio test was conducted to determine the interaction between LDL-C grouping and subgroup variables. All confounding variables, except the effect variable, were 
adjusted in the interaction test performed to analyze the effect variable. All $P$-values less than 0.05 were considered statistically significant.

\section{Results}

The sample comprised 3684 participants. The mean age was $64 \pm 13$ years old and $43.7 \%$ were male. The median follow-up time (interquartile range) was 3160 (23303693) days. A total of 326 (8.8\%) participants were confirmed to have died, and of these, 180 were men $(11.2 \%$ of all men) and 146 were women ( $7.0 \%$ of all women) (Table 1).

Table 2 shows the baseline characteristics of the study participants according to LDL-C concentration at baseline. Age, SBP, and BG were higher, while eGFR and SUA levels were lower as LDL-C levels increased. The proportions of participants with hypertriglyceridemia, low HDL-cholesterolemia, and hyperuricemia were the

Table 1 Baseline characteristics of participants

\begin{tabular}{|c|c|}
\hline Characteristics $N=3684$ & Value \\
\hline Gender (male), \% & 43.7 \\
\hline Age (years) & $64 \pm 13$ \\
\hline Body mass index categories ${ }^{\mathrm{a}}, \%$ & $5.0 / 67.8 / 27.2$ \\
\hline Body mass index $\left(\mathrm{kg} / \mathrm{m}^{2}\right)$ & $23.3 \pm 3.2$ \\
\hline Smoking habits (non/ex/light/heavy), \% & $66.4 / 25.6 / 2.7 / 5.2$ \\
\hline Drinking habits (non/occasional/light/heavy), \% & $51.7 / 25.8 / 13.6 / 9.0$ \\
\hline History of cardiovascular disease, $\%$ & 8.0 \\
\hline Hypertension, \% & 57.0 \\
\hline Systolic blood pressure $(\mathrm{mmHg})$ & $138 \pm 21$ \\
\hline Diastolic blood pressure $(\mathrm{mmHg})$ & $80 \pm 11$ \\
\hline Hypertriglyceridemia, \% & 18.0 \\
\hline Triglyceridemia (mg/dL) & $93(70-131)$ \\
\hline Low HDL-cholesterolemia, \% & 4.4 \\
\hline HDL cholesterol (mg/dL) & $63 \pm 16$ \\
\hline Lipid-lowering medication, $\%$ & 9.7 \\
\hline LDL cholesterol (mg/dL) & $118 \pm 31$ \\
\hline LDL cholesterol categories ${ }^{\mathrm{b}}, \%$ & $4.9 / 15.1 / 60.0 / 20.0$ \\
\hline Diabetes, \% & 9.5 \\
\hline Blood glucose (mg/dL) & $100(91-114)$ \\
\hline Chronic kidney disease, \% & 10.2 \\
\hline $\mathrm{eGFR}\left(\mathrm{mL} / \mathrm{min} / 1.73 \mathrm{~m}^{2}\right)$ & $78.0 \pm 16.4$ \\
\hline Hyperuricemia, \% & 13.5 \\
\hline Serum uric acid (mg/dL) & $5.1 \pm 1.4$ \\
\hline
\end{tabular}

$H D L$ high-density lipoprotein, $L D L$ low-density lipoprotein, eGFR estimated glomerular filtration ratio

a Body mass index categories: $<18.5 \mathrm{~kg} / \mathrm{m}^{2}, 18.5-25.0 \mathrm{~kg} / \mathrm{m}^{2}, \geq 25 \mathrm{~kg} / \mathrm{m}^{2}$

b LDL cholesterol categories: very low, $<70 \mathrm{mg} / \mathrm{dL}$; low, $70-92 \mathrm{mg} / \mathrm{dL}$; medium, $93-143 \mathrm{mg} / \mathrm{dL} ;$ high, $\geq 144 \mathrm{mg} / \mathrm{dL}$

Data are presented as means \pm standard deviation except for the data for triglycerides and hemoglobin A1c, which were skewed and are thus presented as median (interquartile range) values highest in the very low LDL-C group $(<70 \mathrm{mg} / \mathrm{dL})$. There were no statistically significant differences between LDL-C groups for other characteristics, including frequency of CVD, hypertension, diabetes, and CKD.

Kaplan-Meier survival curves were charted for survival days and cumulative survival rates to identify patterns in the relationships between the four LDL-C groups and allcause mortality (Fig. 2). The cumulative survival rate was significantly lower for individuals with LDL-C levels that were very low $(<70 \mathrm{mg} / \mathrm{dL})$ or low $(93-143 \mathrm{mg} / \mathrm{dL}) \mathrm{com}$ pared with those with high LDL-C levels $(\geq 144 \mathrm{mg} / \mathrm{dL}$ ) (HR: $P=0.002$ and $P<0.001$, respectively).

The HRs and $95 \%$ CIs for the quantitative and categorical variables that were identified as predictors of mortality in the multivariable analysis are presented in Table 3. Among the variables in the model, significant predictors for all-cause mortality were gender (male), older age, BMI under $18.5 \mathrm{~kg} / \mathrm{m}^{2}$, lower LDL-C levels, and diabetes. Compared with individuals with high LDLC levels $(\geq 144 \mathrm{mg} / \mathrm{dL}$ ), the multivariable-adjusted HR (95\% CI) for all-cause mortality was $2.54(1.58-4.07)$ for those with very low LDL-C levels $(<70 \mathrm{mg} / \mathrm{dL}), 1.71$ (1.15-2.54) for those with low LDL-C levels (70-92 mg/ $\mathrm{dL})$, and $1.21(0.87-1.68)$ for those with medium LDL-C levels $(93-143 \mathrm{mg} / \mathrm{dL})$.

Table 4 shows a higher prevalence of all-cause mortality in the very low and low LDL-C groups compared with the high LDL-C group. Next, participants were divided into four groups by age $(<55,55-64,65-74$, and $\geq$ 75 years), and the analysis was adjusted for gender, age, BMI, smoking and drinking status, history of CVD, hypertension, hypertriglyceridemia, low HDLcholesterolemia, use of lipid-lowering medication, CKD, and hyperuricemia. In participants below 55 years of age, there were no significant associations between the four LDL-C groups. In participants aged 55 years and older, very low $\mathrm{LDL}-\mathrm{C}$ levels $(<70 \mathrm{mg} / \mathrm{dL})$ were significantly associated with an increased risk of all-cause mortality, and among those aged 75 years and older, even those with LDL-C below $92 \mathrm{mg} / \mathrm{dl}$ had an increased risk.

Lastly, participants were stratified in Table 5 by gender, BMI $\left(<25\right.$ and $\left.\geq 25 \mathrm{~kg} / \mathrm{m}^{2}\right)$, history of CVD, hypertension, diabetes, and CKD status, use of lipid-lowering medication, and time to death $(<1095$ or $\geq 1095$ days). Overall, the results showed that very low $(<70 \mathrm{mg} / \mathrm{dL})$ and low $(70-92 \mathrm{mg} / \mathrm{dL})$ LDL-C levels were associated with a higher risk of all-cause mortality, and this association was particularly significant among participants who were male $(P=0.039$ for interaction) and had CKD $(P=0.015$ for interaction).

\section{Discussion}

The main finding of this cohort study is that LDL-C is a significant and independent predictor of all-cause 
Table 2 Baseline characteristics of participants by low-density lipoprotein cholesterol categories

\begin{tabular}{|c|c|c|c|c|c|}
\hline \multirow[b]{3}{*}{ Characteristics $N=3684$} & \multicolumn{4}{|c|}{ LDL cholesterol categories (mg/dL) } & \multirow[b]{3}{*}{$\begin{array}{l}P \text {-value } \\
*\end{array}$} \\
\hline & $\begin{array}{l}\text { Very Low } \\
(<5 \%) \\
<70\end{array}$ & $\begin{array}{l}\text { Low } \\
(5-19 \%) \\
70-92\end{array}$ & $\begin{array}{l}\text { Medium } \\
(20-79 \%) \\
93-143\end{array}$ & $\begin{array}{l}\text { High } \\
(\geq 80 \%) \\
\geq 144\end{array}$ & \\
\hline & $N=181$ & $N=555$ & $N=2212$ & $N=736$ & \\
\hline Gender (male), \% & 78.5 & 59.1 & 41.6 & 29.9 & $<0.001$ \\
\hline Age (years) & $59 \pm 17$ & $61 \pm 15$ & $65 \pm 12$ & $65 \pm 11$ & $<0.001$ \\
\hline Body mass index categories ${ }^{a}, \%$ & $10.5 / 70.7 / 18.8$ & 7.4/69.9/22.7 & 4.5/68.4/27.0 & 3.3/63.5/33.3 & $<0.001$ \\
\hline Body mass index $\left(\mathrm{kg} / \mathrm{m}^{2}\right)$ & $22.3 \pm 3.3$ & $22.7 \pm 3.2$ & $23.3 \pm 3.1$ & $23.9 \pm 3.3$ & $<0.001$ \\
\hline Smoking habits ( $\mathrm{non}=1$, ex $=2$, light $=3$, heavy $=4$ ), $\%$ & $43.6 / 50.3 / 1.7 / 4.4$ & $55.1 / 35.3 / 2.5 / 7.0$ & $68.8 / 22.7 / 3.0 / 5.5$ & $\begin{array}{l}73.6 / 20.9 / 2.2 / \\
3.3\end{array}$ & $<0.001$ \\
\hline $\begin{array}{l}\text { Drinking habits ( } \text { non }=1 \text {, occasional }=2 \text {, light }=3 \text {, heavy }=4 \text { ), } \\
\%\end{array}$ & $\begin{array}{l}23.2 / 22.7 / 24.9 / \\
29.3\end{array}$ & $\begin{array}{l}37.8 / 29.5 / 20.5 / \\
12.1\end{array}$ & $\begin{array}{l}53.3 / 26.1 / 12.5 / \\
8.0\end{array}$ & $\begin{array}{l}64.1 / 22.6 / 8.7 / \\
4.6\end{array}$ & $<0.001$ \\
\hline History of cardiovascular disease, $\%$ & 6.1 & 8.6 & 8.5 & 6.7 & 0.303 \\
\hline Hypertension, \% & 53.6 & 52.3 & 58.1 & 58.3 & 0.057 \\
\hline Systolic blood pressure (mmHg) & $136 \pm 20$ & $135 \pm 21$ & $138 \pm 21$ & $139 \pm 22$ & 0.001 \\
\hline Diastolic blood pressure (mmHg) & $80 \pm 12$ & $79 \pm 12$ & $80 \pm 11$ & $81 \pm 12$ & 0.001 \\
\hline Hypertriglyceridemia, \% & 32.0 & 12.1 & 16.7 & 23.0 & $<0.001$ \\
\hline Triglyceridemia (mg/dL) & $100(60-179)$ & $81(61-114)$ & $91(69-127)$ & $105(81-145)$ & $<0.001$ \\
\hline Low HDL-cholesterolemia, \% & 9.4 & 4.9 & 3.8 & 4.9 & 0.004 \\
\hline HDL cholesterol (mg/dL) & $60 \pm 19$ & $63 \pm 18$ & $63 \pm 15$ & $61 \pm 15$ & $<0.001$ \\
\hline Lipid-lowering medication, \% & 6.6 & 11.0 & 10.5 & 6.9 & 0.011 \\
\hline LDL cholesterol (mg/dL) & $58 \pm 9$ & $82 \pm 6$ & $118 \pm 14$ & $162 \pm 18$ & $<0.001$ \\
\hline Diabetes, \% & 11.0 & 8.5 & 9.7 & 9.4 & 0.733 \\
\hline Blood glucose (mg/dL) & $97(89-111)$ & $98(89-114)$ & $100(91-114)$ & $103(92-117)$ & 0.002 \\
\hline Chronic kidney disease, \% & 11.6 & 9.0 & 10.2 & 10.6 & 0.712 \\
\hline eGFR (mL/min/1.73 m²) & $82.9 \pm 20.0$ & $80.7 \pm 17.4$ & $77.6 \pm 16.1$ & $76.2 \pm 15.1$ & $<0.001$ \\
\hline Hyperuricemia, \% & 26.5 & 15.0 & 12.5 & 12.2 & $<0.001$ \\
\hline Serum uric acid (mg/dL) & $5.8 \pm 1.6$ & $5.2 \pm 1.5$ & $5.1 \pm 1.4$ & $5.1 \pm 1.4$ & $<0.001$ \\
\hline
\end{tabular}

${ }^{a}$ Body mass index categories: $<18.5 \mathrm{~kg} / \mathrm{m}^{2}, 18.5-25.0 \mathrm{~kg} / \mathrm{m}^{2}, \geq 25 \mathrm{~kg} / \mathrm{m}^{2}$. Data presented are means \pm standard deviation. Data for triglycerides and Hemoglobin A1c were skewed and are thus presented as median (interquartile range) values, and were log-transformed for analysis. ${ }^{*} P$-values are from ANOVA for continuous variables or from the $x^{2}$-test for categorical variables. Significant values $(P<0.05)$ are presented in bold

mortality in community-dwelling adults. After adjustment for possible confounding factors, the results showed that participants with the very low LDL-C levels $(<70 \mathrm{mg} / \mathrm{dL})$ were at a significantly higher risk for allcause mortality than those with high LDL-C levels $(\geq$ $144 \mathrm{mg} / \mathrm{dL}$ ). To the best of our knowledge, few studies have demonstrated the relationship between LDL-C level and all-cause mortality in Japanese community-dwelling persons.

The results of this study, especially that low LDL-C levels are significantly associated with an increased risk of all-cause mortality, are consistent with the results of several existing studies. The Kangbuk Samsung Health Study on 347,971 individuals (mean age: 39.6 years old; male: 57.4\%; mean follow-up: $5.64 \pm 3.27$ years) highlighted that the lowest LDL-C group $(<70 \mathrm{mg} / \mathrm{dL})$ was at a higher risk of all-cause mortality (HR: 1.81; 95\%
CI: 1.44-2.28) compared with the reference group (120$139 \mathrm{mg} / \mathrm{dL}$ ) [7]. Further, Johannesen et al. [16] reported 2028 deaths among the total number of participants and 11,376 (10.5\%) deaths during the study among the 108,243 individuals aged $20-100$ years (male: $45.0 \%$; median follow-up: 9.4 years). The study also showed a Ushaped relationship between LDL-C levels and the risk of all-cause mortality: that is, low levels $(<70 \mathrm{mg} / \mathrm{dL}$; HR: 1.25 , 95\% CI: 1.15-1.36) and high levels (> $189 \mathrm{mg} /$ dL; HR: 1.15 , 95\% CI: 1.05-1.27) were associated with an increased risk of all-cause mortality compared with the reference group $(132-154 \mathrm{mg} / \mathrm{L})$. The China Health and Retirement Longitudinal Study (follow-up: 4 years) recorded a total of 305 deaths out of 4981 male participants. Compared with the LDL-C baseline group (117$137 \mathrm{mg} / \mathrm{dL})$, a lower LDL-C level $(\leq 84 \mathrm{mg} / \mathrm{dL})$ was associated with an increased risk of four-year all-cause 


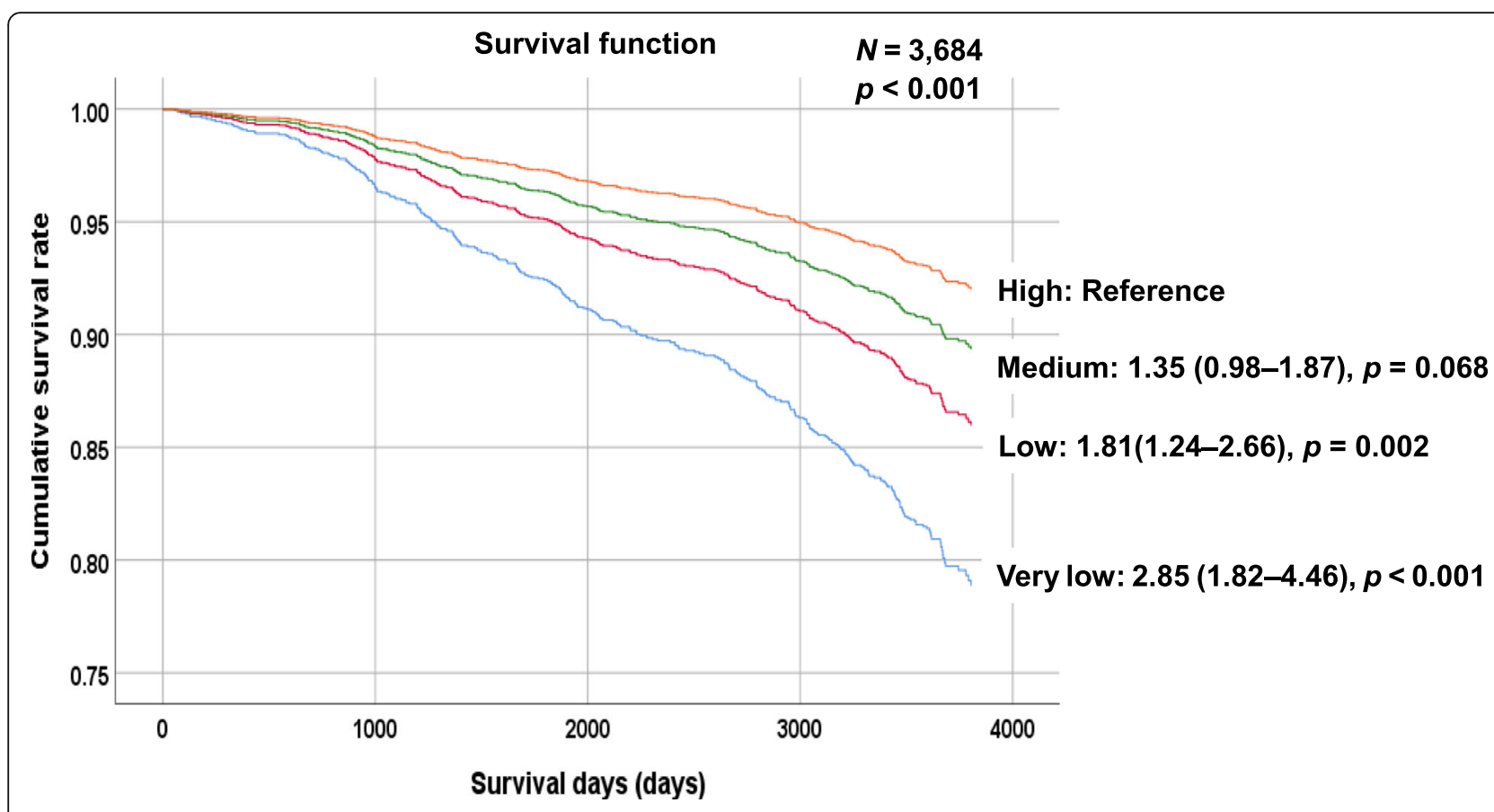

Fig. 2 Analysis of the association between low-density lipoprotein cholesterol groups and all-cause mortality during the follow-up period using a survival function. $P$-values were obtained through a log-rank test of equality across various strata

Table 3 Multivariable-adjusted hazard ratios and 95\% confidence intervals of baseline characteristics for all-cause mortality

\begin{tabular}{|c|c|c|c|}
\hline Characteristics $N=3684$ & & HR $(95 \% \mathrm{Cl})$ & $P$-value \\
\hline Gender (female $=1$, male $=2$ ) & 2 vs 1 & $1.43(1.04-1.98)$ & 0.027 \\
\hline Age (per 1 year) & - & $1.09(1.08-1.11)$ & $<0.001$ \\
\hline Body mass index categories $\left(<18.5 \mathrm{~kg} / \mathrm{m}^{2}=1,18.5-24.9 \mathrm{~kg} / \mathrm{m}^{2}=2, \geq 25.0 \mathrm{~kg} / \mathrm{m}^{2}=3\right.$ ) & $\begin{array}{l}2 \text { vs } 1 \\
3 \text { vs } 1\end{array}$ & $\begin{array}{l}0.51(0.35-0.75) \\
0.40(0.26-0.63)\end{array}$ & $\begin{array}{l}0.001 \\
<0.001\end{array}$ \\
\hline Smoking habits (non $=1$, ex $=2$, light $=3$, heavy $=4$ ) & $\begin{array}{l}2 \text { vs } 1 \\
3 \text { vs } 1 \\
4 \text { vs } 1\end{array}$ & $\begin{array}{l}1.29(0.97-1.72) \\
0.34(0.11-1.07) \\
0.97(0.50-1.90)\end{array}$ & $\begin{array}{l}0.085 \\
0.064 \\
0.934\end{array}$ \\
\hline Drinking habits ( non $=1$, occasional $=2$, light $=3$, heavy $=4$ ) & $\begin{array}{l}2 \text { vs } 1 \\
3 \text { vs } 1 \\
4 \text { vs } 1\end{array}$ & $\begin{array}{l}1.02(0.76-1.38) \\
0.85(0.59-1.23) \\
0.95(0.61-1.49)\end{array}$ & $\begin{array}{l}0.880 \\
0.394 \\
0.834\end{array}$ \\
\hline History of cardiovascular disease ( $\mathrm{no}=1$, yes $=2$ ) & 2 vs 1 & $1.33(0.99-1.80)$ & 0.061 \\
\hline Hypertension ( $\mathrm{no}=1$, yes $=2$ ) & 2 vs 1 & $1.09(0.84-1.40)$ & 0.528 \\
\hline Hypertriglyceridemia ( $\mathrm{no}=1$, yes $=2$ ) & 2 vs 1 & $0.92(0.67-1.26)$ & 0.604 \\
\hline Low HDL-cholesterolemia ( $\mathrm{no}=1$, yes $=2$ ) & 2 vs 1 & $0.54(0.29-1.00)$ & 0.052 \\
\hline LDL cholesterol categories $(<70 \mathrm{mg} / \mathrm{dL}=1,70-92 \mathrm{mg} / \mathrm{dL}=2,93-143 \mathrm{mg} / \mathrm{dL}=3, \geq 144 \mathrm{mg} / \mathrm{dL}=4)$ & $\begin{array}{l}1 \text { vs } 4 \\
2 \text { vs } 4 \\
3 \text { vs } 4\end{array}$ & $\begin{array}{l}2.54(1.58-4.07) \\
1.71(1.15-2.54) \\
1.21(0.87-1.68)\end{array}$ & $\begin{array}{l}<0.001 \\
\mathbf{0 . 0 0 8} \\
0.250\end{array}$ \\
\hline Lipid-lowering medication ( $\mathrm{no}=1$, yes $=2$ ) & 2 vs 1 & $0.89(0.60-1.31)$ & 0.551 \\
\hline Diabetes $(\mathrm{no}=1$, yes $=2$ ) & 2 vs 1 & $1.66(1.23-2.23)$ & 0.001 \\
\hline Chronic kidney disease $($ no $=1$, yes $=2$ ) & 2 vs 1 & $0.93(0.69-1.27)$ & 0.659 \\
\hline Hyperuricemia ( $\mathrm{no}=1$, yes $=2$ ) & 2 vs 1 & $1.17(0.85-1.60)$ & 0.337 \\
\hline
\end{tabular}


Table 4 Hazard ratios and 95\% confidence intervals of baseline low density lipoprotein cholesterol categories for all-cause mortality by age group

\begin{tabular}{|c|c|c|c|c|}
\hline $\begin{array}{l}\text { LDL } \\
\text { cholesterol }\end{array}$ & $\begin{array}{l}\text { Prevalence of } \\
\text { death/total (\%) }\end{array}$ & $\begin{array}{l}\text { Non-adjusted } \\
\text { HR }(95 \% \mathrm{Cl})\end{array}$ & $\begin{array}{l}\text { Gender and age-adjusted } \\
\text { HR }(95 \% \mathrm{Cl})\end{array}$ & $\begin{array}{l}\text { Multivariable-adjusted } \\
\mathrm{HR}_{(95 \% \mathrm{Cl})^{\mathrm{a}}}\end{array}$ \\
\hline \multicolumn{5}{|c|}{$<55$ years of age $(n=788)$} \\
\hline Very low & $4 / 65(6.2)$ & $7.03(0.79-62.9)$ & $6.47(0.70-59.8)$ & $4.91(0.49-49.6)$ \\
\hline Low & $1 / 168(0.6)$ & $0.71(0.04-11.3)$ & $0.70(0.04-11.3)$ & $0.65(0.04-10.9)$ \\
\hline Medium & 13/431 (3.0) & $3.65(0.48-27.9)$ & $4.03(0.52-30.9)$ & $3.19(0.40-25.4)$ \\
\hline High & $1 / 124(0.8)$ & 1.00 & 1.00 & 1.00 \\
\hline$P$-value & 0.041 & 0.108 & 0.123 & 0.226 \\
\hline \multicolumn{5}{|c|}{$\geq 55$ and $<65$ years of age $(n=783)$} \\
\hline Very low & $4 / 28(14.3)$ & $8.19(1.83-36.6)$ & $6.66(1.40-31.7)$ & $7.04(1.40-35.5)$ \\
\hline Low & 9/99 (9.1) & $5.74(1.55-21.2)$ & $4.66(1.22-17.8)$ & $4.33(1.12-16.8)$ \\
\hline Medium & $19 / 468(4.1)$ & $2.55(0.75-8.62)$ & $2.29(0.67-7.80)$ & $2.24(0.65-7.65)$ \\
\hline High & $3 / 188(1.6)$ & 1.00 & 1.00 & 1.00 \\
\hline$P$-value & 0.002 & 0.009 & 0.042 & 0.057 \\
\hline \multicolumn{5}{|c|}{$\geq 65$ and $<75$ years of age $(n=1395)$} \\
\hline Very low & $9 / 52(17.3)$ & $2.76(1.24-6.15)$ & $2.34(1.02-5.39)$ & $2.52(1.08-5.93)$ \\
\hline Low & 18/179 (10.1) & $1.62(0.84-3.11)$ & $1.43(0.73-2.79)$ & $1.37(0.70-2.69)$ \\
\hline Medium & 60/872 (6.9) & $1.12(0.66-1.89)$ & $1.02(0.60-1.74)$ & $0.93(0.54-1.59)$ \\
\hline High & 18/292 (6.2) & 1.00 & 1.00 & 1.00 \\
\hline$P$-value & 0.007 & 0.037 & 0.109 & 0.044 \\
\hline \multicolumn{5}{|c|}{$\geq 75$ years of age $(n=718)$} \\
\hline Very low & 16/36 (44.4) & $3.03(1.61-5.71)$ & $2.53(1.33-4.84)$ & $2.13(1.09-4.16)$ \\
\hline Low & $34 / 109(31.2)$ & $2.27(1.35-3.84)$ & $1.99(1.17-3.39)$ & $1.75(1.01-3.05)$ \\
\hline Medium & $93 / 441(21.1)$ & $1.27(0.81-1.98)$ & $1.22(0.78-1.92)$ & $1.09(0.68-1.73)$ \\
\hline High & 24/132 (18.2) & 1.00 & 1.00 & 1.00 \\
\hline$P$-value & $<0.001$ & $<0.001$ & 0.004 & 0.021 \\
\hline
\end{tabular}

HR hazard ratio, $C l$ confidence interval, $L D L$ cholesterol categories: very low, $<70 \mathrm{mg} / \mathrm{dL}$; low, $70-92 \mathrm{mg} / \mathrm{dL} ; \mathrm{medium}, 93-143 \mathrm{mg} / \mathrm{dL} ;$ high, $\geq 144 \mathrm{mg} / \mathrm{dL}$ a Multivariate-adjusted HR: adjusted for gender, age, body mass index categories, smoking status, drinking status, history of cardiovascular disease, hypertension, hypertriglyceridemia, low HDL-cholesterolemia, lipid-lowering medication, chronic kidney disease, and hyperuricemia

Significant values $(P<0.05)$ are presented in bold

mortality in middle-aged and older adult Chinese male participants [17]. According to a recent systematic review of 19 cohort studies with more than 68,094 older adults, all-cause mortality was highest in the lowest LDL-C quartile group [18]. In addition, a populationbased register study on 118,160 individuals aged 50 years or older without baseline statin use showed an association between high LDL-C levels and lower mortality among older adults [10]. The present study also reports that low LDL-C levels at baseline, as well as being male, older, having lower BMI, and having a history of diabetes, were linked with an increase in all-cause mortality. The association between LDL-C levels and all-cause mortality was particularly significant for male participants and those who have CKD. The opposite trend was not observed in people with a BMI of $25 \mathrm{~kg} / \mathrm{m}^{2}$ or higher, those with a history of CVD, or those with diabetes. Higher LDL-C levels are often observed in these patient groups $[19,20]$, but this does not necessarily lead to increased mortality [21]. In addition, for those with low LDL-C levels due to lipid-lowering medication, allcause mortality was not significantly increased; for these individuals, low LDL-C levels were intentional, rather than an indicator of poor prognosis. However, in the study with 118,160 participants, it was reported that those with the highest LDL-C levels lived longer than those on lipid-lowering medication [10].

The study examined the association between LDL-C levels and mortality outcomes in a real-world setting among community-dwelling individuals, including those on lipid-lowering therapy and those with a baseline history of CVD, hypertension, or diabetes. However, the sub-analysis shows similar notable findings for those who were not undergoing lipid-lowering therapy or had no other diseases. The findings suggest that considerably lower LDL-C levels do not necessarily protect against 
Table 5 Hazard ratios and 95\% confidence intervals of baseline low density lipoprotein cholesterol categories for all-cause mortality by sub-analysis

\begin{tabular}{|c|c|c|c|c|c|}
\hline \multirow{2}{*}{$\begin{array}{l}\text { Characteristics } \\
N=3684\end{array}$} & \multicolumn{3}{|c|}{ Multivariable-adjusted HR $(95 \% \mathrm{Cl})$} & \multirow[t]{2}{*}{$P$-value } & \multirow{2}{*}{$\begin{array}{l}P \text { for } \\
\text { interaction }\end{array}$} \\
\hline & Very low & Low & Medium & & \\
\hline \multicolumn{6}{|l|}{ Gender } \\
\hline Male $(n=1610)$ & $2.80(1.53-5.14)$ & $1.84(1.05-3.22)$ & $0.98(0.58-1.66)$ & $<0.001$ & \multirow[t]{2}{*}{0.039} \\
\hline Female $(n=2074)$ & $1.42(0.42-4.74)$ & $1.41(0.73-2.70)$ & $1.44(0.94-2.19)$ & 0.407 & \\
\hline \multicolumn{6}{|l|}{ Body mass index } \\
\hline$<25 \mathrm{~kg} / \mathrm{m}^{2}(n=2681)$ & $2.43(1.46-4.05)$ & $1.66(1.07-2.58)$ & $1.02(0.70-1.48)$ & $<0.001$ & \multirow[t]{2}{*}{0.261} \\
\hline$\geq 25 \mathrm{~kg} / \mathrm{m}^{2}(n=1003)$ & $2.36(0.62-9.04)$ & $1.46(0.54-3.94)$ & $1.89(0.94-3.79)$ & 0.308 & \\
\hline \multicolumn{6}{|c|}{ History of cardiovascular disease } \\
\hline No $(n=3389)$ & $2.63(1.59-4.35)$ & $1.62(1.04-2.50)$ & $1.15(0.81-1.64)$ & $<0.001$ & \multirow[t]{2}{*}{0.907} \\
\hline Yes $(n=295)$ & $1.64(0.39-6.93)$ & $3.03(1.03-8.84)$ & $1.41(0.52-3.82)$ & 0.099 & \\
\hline \multicolumn{6}{|l|}{ Hypertension } \\
\hline No $(n=1583)$ & $3.19(1.35-7.56)$ & $1.71(0.80-3.66)$ & $1.32(0.71-2.45)$ & 0.044 & \multirow[t]{2}{*}{0.705} \\
\hline Yes $(n=2101)$ & $2.35(1.33-4.16)$ & $1.80(1.13-2.88)$ & $1.16(0.79-1.70)$ & 0.002 & \\
\hline \multicolumn{6}{|l|}{ Lipid-lowering medication } \\
\hline No $(n=3327)$ & $2.75(1.66-4.55)$ & $2.06(1.35-3.14)$ & $1.31(0.92-1.86)$ & $<0.001$ & \multirow[t]{2}{*}{0.379} \\
\hline Yes $(n=357)$ & $3.74(0.91-15.4)$ & $0.31(0.08-1.17)$ & $0.49(0.19-1.28)$ & 0.003 & \\
\hline \multicolumn{6}{|l|}{ Diabetes } \\
\hline No $(n=3334)$ & $3.32(2.00-5.52)$ & $1.85(1.19-2.86)$ & $1.21(0.84-1.75)$ & $<0.001$ & \multirow[t]{2}{*}{0.059} \\
\hline Yes $(n=350)$ & $0.78(0.19-3.17)$ & $1.21(0.45-3.24)$ & $1.04(0.48-2.27)$ & 0.937 & \\
\hline \multicolumn{6}{|l|}{ Chronic kidney disease } \\
\hline No $(n=3310)$ & $1.92(1.11-3.32)$ & $1.48(0.96-2.28)$ & $1.04(0.73-1.47)$ & 0.017 & \multirow[t]{2}{*}{0.015} \\
\hline Yes $(n=374)$ & $8.69(2.77-27.3)$ & $4.89(1.62-14.7)$ & $2.50(0.94-6.59)$ & $<0.001$ & \\
\hline \multicolumn{6}{|l|}{ Time to death } \\
\hline$<1095$ days $(\mathrm{n}=73)$ & Not examined & Not examined & Not examined & - & \multirow[t]{2}{*}{ Not examined } \\
\hline$\geq 1095$ days $(n=3611)$ & $2.68(1.67-4.28)$ & $1.74(1.17-2.59)$ & $1.20(0.86-1.66)$ & $<0.001$ & \\
\hline
\end{tabular}

$H R$ hazard ratio, $C l$ confidence interval, $L D L$ cholesterol categories: very low, $<70 \mathrm{mg} / \mathrm{dL}$; low, 70-92 mg/dL; medium, 93-143 mg/dL; high, $\geq 144 \mathrm{mg} / \mathrm{dL}=$ Reference

a Multivariate-adjusted HR: adjusted for gender, age, body mass index categories, smoking status, drinking status, history of cardiovascular disease, hypertension, hypertriglyceridemia, low HDL-cholesterolemia, lipid-lowering medication, chronic kidney disease, and hyperuricemia. Significant values ( $p<0.05)$ are presented in bold

all-cause mortality among community-dwelling persons who are not on lipid-lowering medication, thus supporting the lipid paradox [7]. In addition, the difference in results between male and female participants can be attributed to fewer deaths among women than men, which results in insufficient association power [17]. We believed that baseline serum LDL-C levels would be positively associated with CVD [22] and mortality in middleaged people. On the other hand, a negative association between LDL-C levels and all-cause mortality has been observed in the elderly [23, 24]. In this population, mortality from non-CVD increased with decreasing LDL-C, which could be due to malnutrition or infectious diseases [25-28]. This would explain the reversed association between LDL-C levels and all-cause mortality that was only observed in the older population. We discuss this further in the following paragraph. In our study, the reversed association was consistently found in the age group of 55 years and older, but no significant association was found among the four LDL-C groups in participants younger than 55 years.

The mechanisms leading to increased all-cause mortality in individuals with very low LDL-C levels are not completely understood. Several explanations can be offered for these findings. Low LDL-C levels increase susceptibility to serious diseases [29]. Conversely, it has been hypothesized that frailty and illnesses lower cholesterol levels [30]. The latter concerns that cholesterol may be lowered by serious diseases shortly before death could be dispelled because mortality during the 3 years of observation were excluded in the current study. LDL$\mathrm{C}$ may protect against viruses and cancers caused by viruses, and is therefore a component of innate immunity [26]. Ravnskov et al. [27] reviewed nine cohort studies 
involving more than 140,000 individuals. The review showed that the occurrence of cancer was inversely associated with cholesterol levels measured 10-30 years earlier, and the association remained when cancer cases that appeared during the first 4 years were excluded. Moreover, the lowering of lipids in rodents have led to cancer in previous experiments [25]. In addition, exotoxins produced by Gram-positive bacteria are absorbed by LDL-C [31]. Thus, higher LDL-C levels have been associated with reduced infection-related mortality and other nonCVD mortality, which explains the inverse relationship with all-cause mortality [28]. In this study, comorbidities such as hypertriglyceridemia, low HDL cholesterolemia, and hyperuricemia were more frequently observed in individuals with the lowest LDL-C levels. Finally, the relationship between LDL-C and mortality from coronary artery disease has also been reported in a paradoxical hypothesis regarding the relationship with mortality, and patients with higher LDL-C at admission had not higher all-cause mortality compared to patients with normal or low LDL-C [32, 33]. If high LDL-C were the cause, the effect should have been the opposite.

\section{Study strengths and limitations}

The strengths of this study are the fact that it is a longterm follow-up collection, the sample size, the adjustment for possible confounding factors, and the inclusion of sensitivity analyses. However, the authors acknowledge some limitations. First, the sample consisted mainly of relatively healthy middle-aged and elderly people (mean age: $64 \pm 13$ years) who lived in rural areas of Japan and participated in the health checkup. Therefore, it cannot be considered representative of the general population. Second, the survey covered people whose deaths were registered in the basic resident register. Those who moved out of the region during the survey period are not included. Third, the possible effects of medication (e.g., antihypertensive, lipid-lowering, and antidiabetic medication), underlying diseases, and lifestyle modifications at the baseline and during the followup period on the present findings cannot be overlooked. Fourth, the threshold for the high LDL-C group may have been too low to evaluate the U-shaped relationship between LDL-C levels and all-cause mortality. If high LDL-C was defined as $190 \mathrm{mg} / \mathrm{dL}$ or higher in this study, the high LDL-C group would have included 52 individuals, with a $7.7 \%$ mortality rate during the observation period, which was not significantly different from the reference value (data not shown). Fifth, this study did not measure certain specific lipoproteins (e.g., small dense LDL), which could be a possible explanation for this phenomenon. Finally, the relatively low number of participants and deaths may weaken the causal relationship between LDL-C levels and all-cause mortality.

\section{Conclusions}

The current results, based on a follow-up study of people aged 22 years and older, show that having very low LDL-C levels $(<70 \mathrm{mg} / \mathrm{dL})$ is predictive of higher all-cause mortality, after adjustment for potential confounders such as body composition indices and metabolic factors. Therefore, further attention to individuals for whom lower LDL-C levels are not induced by lipidlowering medication may be necessary.

\section{Acknowledgements \\ We thank Uni-edit (https://uni-edit.net/) for editing and proofreading this manuscript.}

\section{Authors' contributions}

RK and AK participated in the design of the study, performed the statistical analysis and drafted the manuscript. RK, AK, DN, TA, and TK contributed to the acquisition and interpretation of data. RK and AK contributed to the conception and design of the statistical analysis. RK conceived of the study, participated in its design, coordination and helped to draft the manuscript. All authors read and approved the manuscript.

\section{Funding}

This work was partially supported by a Grant-in-Aid for Scientific Research from the Foundation for Development of Community (2021). No additional external funding was received. The funders played no role in the study design, data collection and analysis, decision to publish, or manuscript preparation.

Availability of data and materials

The participant survey data supporting the conclusions of this manuscript are not publicly available due to protection of the privacy of the participants.

\section{Declarations}

Ethics approval and consent to participate

The study was approved by the ethics committee of the Ehime University Graduate School of Medicine (IRB: no. 1903018) and informed consent was obtained from all subjects participating in the study.

\section{Consent for publication}

Not applicable.

\section{Competing interests}

The authors declare that they have no competing interests.

Received: 5 June 2021 Accepted: 29 August 2021

Published online: 12 September 2021

\section{References}

1. Ference BA, Ginsberg HN, Graham I, Ray KK, Packard CJ, Bruckert E, et al. Low-density lipoproteins cause atherosclerotic cardiovascular disease. 1. Evidence from genetic, epidemiologic, and clinical studies. A consensus statement from the European atherosclerosis society consensus panel. Eur Heart J. 2017;38(32):2459-72. https://doi.org/10.1093/eurheartj/ehx144.

2. Sabatine MS, Wiviott SD, Im K, Murphy SA, Giugliano RP. Efficacy and safety of further lowering of low-density lipoprotein cholesterol in patients starting with very low levels: a Meta-analysis. JAMA Cardiol. 2018;3(9):823-8. https://doi.org/10.1001/jamacardio.2018.2258.

3. Navarese EP, Robinson JG, Kowalewski M, Kołodziejczak M, Andreotti F, Bliden $\mathrm{K}$, et al. Association between baseline LDL-C level and Total and cardiovascular mortality after LDL-C lowering: a systematic review and Meta-analysis. JAMA. 2018;319(15):1566-79. https://doi.org/10.1001/jama.201 8.2525 .

4. Ference BA, Yoo W, Alesh I, Mahajan N, Mirowska KK, Mewada A, et al. Effect of long-term exposure to lower low-density lipoprotein cholesterol beginning early in life on the risk of coronary heart disease: a Mendelian randomization analysis. J Am Coll Cardiol. 2012;60(25):2631-9. https://doi. org/10.1016/j.jacc.2012.09.017. 
5. Baigent C, Blackwell L, Emberson J, Holland LE, Reith C, Bhala N, et al. Efficacy and safety of more intensive lowering of LDL cholesterol: a metaanalysis of data from 170,000 participants in 26 randomised trials. Lancet. 2010;376(9753):1670-81. https://doi.org/10.1016/S0140-6736(10)61350-5.

6. Abdullah SM, Defina LF, Leonard D, Barlow CE, Radford NB, Willis BL, et al. Long-term Association of low-Density Lipoprotein Cholesterol with Cardiovascular Mortality in individuals at low 10-year risk of atherosclerotic cardiovascular disease. Circulation. 2018;138(21):2315-25. https://doi.org/1 0.1161/CIRCULATIONAHA.118.034273.

7. Sung KC, Huh JH, Ryu S, Lee JY, Scorletti E, Byrne CD, et al. Low levels of low-density lipoprotein cholesterol and mortality outcomes in non-statin users. J Clin Med. 2019;8(10). https://doi.org/10.3390/jcm8101571.

8. Schupf N, Costa R, Luchsinger J, Tang MX, Lee JH, Mayeux R. Relationship between plasma lipids and all-cause mortality in nondemented elderly. J Am Geriatr Soc. 2005;53(2):219-26. https://doi.org/10.1111/j.1532-5415.2005. 53106.x.

9. Akerblom JL, Costa R, Luchsinger JA, Manly JJ, Tang M-X, Lee JH, et al. Relation of plasma lipids to all-cause mortality in Caucasian, AfricanAmerican and Hispanic elders. Age Ageing. 2008;37(2):207-13. https://doi. org/10.1093/ageing/afn017.

10. Bathum L, Depont Christensen R, Engers Pedersen L, Lyngsie Pedersen P, Larsen J, Nexøe J. Association of lipoprotein levels with mortality in subjects aged 50 + without previous diabetes or cardiovascular disease: a population-based register study. Scand J Prim Health Care. 2013;31(3):17280. https://doi.org/10.3109/02813432.2013.824157.

11. Lv YB, Yin ZX, Chei CL, Qian HZ, Kraus VB, Zhang J, et al. Low-density lipoprotein cholesterol was inversely associated with 3-year all-cause mortality among Chinese oldest old: data from the Chinese longitudinal healthy longevity survey. Atherosclerosis. 2015;239(1):137-42. https://doi. org/10.1016/j.atherosclerosis.2015.01.002

12. Fried LP, Kronmal RA, Newman AB, Bild DE, Mittelmark MB, Polak JF, et al. Risk factors for 5-year mortality in older adults: the cardiovascular health study. Jama. 1998;279(8):585-92. https://doi.org/10.1001/jama.279.8.585.

13. Nilsson G, Öhrvik J, Lönnberg I, Hedberg P. Ten-year survival in 75-year-old men and women: predictive ability of Total cholesterol, HDL-C, and LDL-C. Curr Gerontol Geriatr Res. 2009;2009:158425.

14. Kawamoto R, Ninomiya D, Kumagi T. Handgrip strength is positively associated with mildly elevated serum bilirubin levels among communitydwelling adults. Tohoku J Exp Med. 2016;240(3):221-6. https://doi.org/10.162 0/tjem.240.221.

15. Horio M, Imai E, Yasuda Y, Watanabe T, Matsuo S. Modification of the CKD epidemiology collaboration (CKD-EPI) equation for Japanese: accuracy and use for population estimates. Am J Kidney Dis. 2010;56(1):32-8. https://doi. org/10.1053/j.ajkd.2010.02.344.

16. Johannesen CDL, Langsted A, Mortensen MB, Nordestgaard BG. Association between low density lipoprotein and all cause and cause specific mortality in Denmark: prospective cohort study. BMJ. 2020;371:m4266.

17. Zhou L, Wu Y, Yu S, Shen Y, Ke C. Low-density lipoprotein cholesterol and all-cause mortality: findings from the China health and retirement longitudinal study. BMJ Open. 2020;10(8):e036976. https://doi.org/10.1136/ bmjopen-2020-036976.

18. Ravnskov U, Diamond DM, Hama R, Hamazaki T, Hammarskjöld B, Hynes N, et al. Lack of an association or an inverse association between low-densitylipoprotein cholesterol and mortality in the elderly: a systematic review. BMJ Open. 2016;6(6):e010401. https://doi.org/10.1136/bmjopen-2015-010401.

19. Klop B, Elte JW, Cabezas MC. Dyslipidemia in obesity: mechanisms and potential targets. Nutrients. 2013;5(4):1218-40. https://doi.org/10.3390/ nu5041218.

20. Vergès B. Pathophysiology of diabetic dyslipidaemia: where are we? Diabetologia. 2015;58(5):886-99. https://doi.org/10.1007/s00125-015-3525-8.

21. Czapla M, Juárez-Vela R, Łokieć K, Karniej P. The association between nutritional status and in-hospital mortality among patients with heart failure-a result of the retrospective nutritional status heart study 2 (NSHS2). Nutrients. 2021;13(5). https://doi.org/10.3390/nu13051669.

22. Grundy SM, Stone NJ, Bailey AL, Beam C, Birtcher KK, Blumenthal RS, Braun LT, de Ferranti S, Faiella-Tommasino J, Forman DE, et al. 2018 AHA/ACC AACVPR/AAPA/ABC/ACPM/ADA/AGS/APhA/ASPC/NLA/PCNA Guideline on the Management of Blood Cholesterol: A Report of the American College of Cardiology/American Heart Association Task Force on Clinical Practice Guidelines. J Am Coll Cardiol. 2019;73:e285-e350. https://doi.org/10.1016/j.ja cc.2018.11.003.
23. Takata Y, Ansai T, Soh I, Awano S, Nakamichi I, Akifusa S, et al. Serum total cholesterol concentration and 10-year mortality in an 85-year-old population. Clin Interv Aging. 2014;9:293-300. https://doi.org/10.2147/CIA. S53754.

24. Wang MC, Hu HY, Lin IF, Chuang JT. Plasma lipid concentrations and survival in geriatric population: a retrospective cohort study. Medicine (Baltimore). 2019;98(49):e18154. https://doi.org/10.1097/MD.00000000000181 54.

25. Newman TB, Hulley SB. Carcinogenicity of lipid-lowering drugs. Jama. 1996; 275(1):55-60. https://doi.org/10.1001/jama.1996.03530250059028.

26. Han R. Plasma lipoproteins are important components of the immune system. Microbiol Immunol. 2010;54(4):246-53. https://doi.org/10.1111/j.134 8-0421.2010.00203.x

27. Ravnskov U, McCully KS, Rosch PJ. The statin-low cholesterol-cancer conundrum. QJM. 2011:105:383-8.

28. Kaysen GA, Ye X, Raimann JG, Wang Y, Topping A, Usvyat LA, et al. Lipid levels are inversely associated with infectious and all-cause mortality: international MONDO study results. J Lipid Res. 2018;59(8):1519-28. https:// doi.org/10.1194/jlr.P084277.

29. Jeong SM, Choi S, Kim K, Kim SM, Lee G, Son JS, et al. Association of change in total cholesterol level with mortality: a population-based study. PLoS One. 2018;13(4):e0196030. https://doi.org/10.1371/journal.pone.0196030.

30. Ranieri P, Rozzini R, Franzoni S, Barbisoni P, Trabucchi M. Serum cholesterol levels as a measure of frailty in elderly patients. Exp Aging Res. 1998;24(2): 169-79. https://doi.org/10.1080/036107398244300.

31. Bhakdi S, Tranum-Jensen J, Utermann G, Füssle R. Binding and partial inactivation of Staphylococcus aureus alpha-toxin by human plasma low density lipoprotein. J Biol Chem. 1983;258(9):5899-904. https://doi.org/10.1 016/S0021-9258(20)81980-2.

32. Reddy VS, Bui QT, Jacobs JR, Begelman SM, Miller DP, French WJ. Relationship between serum low-density lipoprotein cholesterol and inhospital mortality following acute myocardial infarction (the lipid paradox). Am J Cardiol. 2015;115(5):557-62. https://doi.org/10.1016/j.amjcard.2014.12. 006.

33. Wang B, Chen S, Liu J, Liang Y, Meng L, Yan X, et al. Association between baseline LDL-C and prognosis among patients with coronary artery disease and advanced kidney disease. BMC Nephrol. 2021;22(1):168. https://doi.org/1 0.1186/s12882-021-02375-1.

\section{Publisher's Note}

Springer Nature remains neutral with regard to jurisdictional claims in published maps and institutional affiliations.
Ready to submit your research? Choose BMC and benefit from:
- fast, convenient online submission
- thorough peer review by experienced researchers in your field
- rapid publication on acceptance
- support for research data, including large and complex data types
- gold Open Access which fosters wider collaboration and increased citations
- maximum visibility for your research: over $100 \mathrm{M}$ website views per year
At BMC, research is always in progress.
Learn more biomedcentral.com/submissions 